\title{
Erratum to: Arthroscopic lateral acromion resection (ALAR) optimizes rotator cuff tear relevant scapula parameters
}

\author{
Burak Altintas $^{1} \cdot$ Max Kääb ${ }^{1} \cdot$ Stefan Greiner $^{1}$
}

Published online: 23 May 2016

(c) Springer-Verlag Berlin Heidelberg 2016

\section{Erratum to: Arch Orthop Trauma Surg (2016) 136:799-804} DOI 10.1007/s00402-016-2431-y

The author would like to correct the error in the publication of the original article. The corrected detail is given below for your reading.

In the abstract, second sentence of the results section should read as

Also the mean CSA was significantly reduced from $31.6^{\circ} \pm 7.65^{\circ}$ to $25.12^{\circ} \pm 8.29^{\circ}(p=0.018)$.

The online version of the original article can be found under doi:10.1007/s00402-016-2431-y.

\section{Stefan Greiner}

greiner@sporthopaedicum.de

1 Sporthopaedicum Regensburg, Hildegard-von-Bingen-Str. 1, 93053 Regensburg, Germany 